\title{
Effects of Distributed Leadership on Teachers' Job Satisfaction, Organizational Commitment and Organizational Citizenship
}

\author{
Mustafa Samancioglu ${ }^{1 \star}$, Murat Baglibel ${ }^{2}$, Barbara Jeanne Erwin ${ }^{3}$
}

\author{
${ }^{1}$ Independent Researcher, TURKEY \\ ${ }^{2}$ Institute for Globally Distributed Open Research and Education (IGDORE), TURKEY \\ ${ }^{3}$ Indiana University, School of Education, USA \\ ^Corresponding Author: msamancioglu@hotmail.com
}

Citation: Samancioglu, M., Baglibel, M., \& Erwin, B. J. (2020). Effects of Distributed Leadership on Teachers' Job Satisfaction, Organizational Commitment and Organizational Citizenship. Pedagogical Research, 5(2), em0052. https://doi.org/10.29333/pr/6439

\section{ARTICLE INFO}

Received: 2 Dec. 2019

Revised: 12 Dec. 2019

Accepted: 12 Dec. 2019

\begin{abstract}
The aim of this study was to investigate the effects of distributed leadership on the teachers' job satisfaction, organizational citizenship behaviour and commitment. To this aim, Distributed Leadership Inventory (Hulpia, Devos, \& Rosseel 2009a), Job Satisfaction Scale (Andrews \& Whitney 1976), Organizational Commitment Scale (Meyer \& Allen 1991), and Organizational Citizenship Behavior Scale (DiPaola, Tarter, \& Hoy 2005) were applied to 344 teachers working at schools in Gaziantep city of Turkey. For the statistical analysis of the collected data standard multiple regression analysis was employed. Results of the study showed that distributed leadership had a statistically significant effect on teachers' job satisfaction, organizational citizenship behavior and organizational commitment. In terms of sub dimensions of the distributed leadership, while leadership functions dimension statically significantly affected job satisfaction, organizational commitment and organizational citizenship behavior; coherent leadership team subdimension affected only job satisfaction. Some recommendations for educational managers, policymakers and researchers in the area were made according to findings of the study.
\end{abstract}

Keywords: educational leadership, distributed leadership, job satisfaction, organizational commitment, organizational citizenship

\section{INTRODUCTION}

Today's organizations struggle to accord with the rapid changes of the knowledge-based society, and in this context, organizational operations and decision-making are becoming more complex. Widely accepted leadership approaches of the past which were based on rivalry and hierarchy are now regarded as inadequate to overcome the problems of a rapidly changing, getting complicated and globalizing world (Clegg, Clarke, \& Ibarra, 2001). The situation is not different for educational organizations. In many countries, there is an increased tendency towards school-based management, thus the school principal's workload has become heavier and this makes it very hard to fulfil his responsibilities (Bush, 2012). Under these circumstances, the schools have to make their staff and stakeholders participate in the decision-making processes more than they have done in the past to improve themselves and to attain outstanding achievements (Leithwood, Mascall, \& Strauss, 2009).

It can be observed in the educational leadership literature that there is a shift from an understanding solely dependent on the school principal to the collaborative and participatory approaches in which decisions are taken together with the staff, and there is an increased emphasis on the models in which leadership roles are distributed to the stakeholders of organization to solve problems and do things more effectively and efficiently in educational organizations (Fullan, 1993; Weiss \& Cambone, 2000). It is emphasized that distributing leadership roles to the members of organization increases the quality of the decisions, affects the school positively and is more effective than the other leadership approaches (Berjaoui \& Karami-Akkary, 2019; Bush, 2012; Leithwood, Harris, \& Hopkins, 2008).

\section{Distributed Leadership}

Nowadays, the limitations of "One Man" or "Hero" centred leadership models are becoming obvious day by day and are replaced by participatory, collaborative and distributed models (Bush, 2011; Crawford, 2012). It is observed that distributed leadership approach has gained importance as an alternative of traditional leadership theories recently.

Distributed leadership is a concept used to denote to a leadership style that transforms the organization of schools and extends leadership beyond an individual (Bush, 2018; Harris, 2010; Leithwood et al., 2009). Sergiovanni (1987) defines the notion 
of distributed leadership as the mechanism of facilitating active involvement of all members of the organization in the leadership process. Harris (2010, p. 55) identifies distributed leadership as "expanding of leadership roles outside of the formal management positions and administrative authorities".

Albeit the distributed leadership (DL) is a fluid concept, there are some fundamental elements that distinguishes this leadership model from others (Harris \& DeFlaminis, 2016). First of all, leadership is seen as a practice rather than a role or responsibility. The collective interactions among the three components of DL (leaders, followers, and situation) are paramount for practice. The second difference is the targets of leadership. In DL, tasks and influences are distributed among individuals by empowering and providing autonomy. The third difference is an emphasis on the interplay between individual and collective interactions. For DL, individual leadership is equally significant and coexist with other forms of leadership. Individual agency and conjoint agency of multiple actors play a significant role in DL. The fourth difference is about structure. DL dramatically departs from the bureaucratic model by focusing on an interdependent effort between multiple levels of organizational hierarchy by gathering people who have different areas of expertise (Gronn, 2000; Harris, 2010; Harris \& DeFlaminis, 2016; Spillane, 2006; Spillane \& Anderson, 2019; Tam, 2018).

Beyond delegation of authority, distributed leadership is an approach, in which decision-making responsibility is shared with the leadership teams and it is facilitated for the staff to lead organizational activities by means of distributing some part of the school principals' duties to the other staff and in this way reducing their workload (Hartley, 2010). According to Spillane (2006), leadership is distributed among some people and the tasks are carried out with the interaction of leaders in distributed leadership.

Distributed leadership has recently been advocated strongly in the management literature. The number of evidences indicating that it has positive effects on educational outputs is growing (Bush \& Glover, 2012; Harris, 2010; Leithwood et al., 2008). Distributed leadership not only increases teachers' self-efficacy levels and affects them in a positive manner but it also provides a significant contribution to school improvement and school effectiveness (Harris, 2010; Macbeath, 2005; Supovitz, D’Auria, \& Spillane, 2019).

\section{Job Satisfaction}

The term Job Satisfaction (JS) has been defined by many researchers in different ways. According to one of the most widely accepted definition, JS is "a pleasurable or positive emotional state resulting from the appraisal of one's job or job experiences" (Locke, 1976, p. 1304). According to Newstrom and Davis (1993), JS is the state of satisfaction or dissatisfaction of an employee concerned with the job. JS is a concept associated with organizational performance and productivity (Judge et al., 2001). It has been proven that teacher's JS level effects student achievement in terms of both academic and social aspects (Ostroff, 1992).

\section{Organizational Commitment}

Organizational Commitment $(\mathrm{OC})$ is defined as the extent to which individuals' integration and adoption of a desire to pursue membership of the organization (Blau \& Boal, 1987). According to Allen and Meyer (1990), OC is composed of three dimensions; affective commitment, continuance commitment and normative commitment. Affective commitment represents individuals' willingly and voluntarily commitment to organization. High affective commitment means congruity of individual and organizational values. Continuance commitment is the type of commitment that results from requirement and need. According to this type of commitment it is suggested that employees who do not want to give up the advantages of organization and who think leaving the organization would be a significant cost will prefer to stay in organization. Normative OC refers to the commitment resulting from liability-obligation. In this type of commitment, it is considered that due to the pressure of others individuals feel obliged to stay in organization.

Research has shown that OC makes a positive contribution to individuals' commitment to organizational goals by reducing the absenteeism and desire to leave the work (Newstrom \& Davis, 1993; Valentine, Godkin, \& Lucero, 2002). Additionally, researches in the field also emphasize the OC as one of the most important factors affecting organizational success (Fink, 1992). OC of teachers is a major predictor of teacher performance and educational quality (Dee, Henkin, \& Singleton, 2006).

\section{Organizational Citizenship Behaviour}

Organizational Citizenship Behaviour (OCB) is defined as arbitrary behaviour of an individual that is not recognized by the formal reward system, and in the total promotes the performance and functioning of the organization (Organ, 1988). According to another definition, OCB is the extent to which an individual goes beyond the minimum performance expected of him (TschannenMoran, 2003). Employees with a high level of OCB assist a colleague that does not come to work, are willing to do things that are important for organization without any formal obligation, contribute the socialization of newcomers to the organization, help the other employees to solve the problems they face, suggest new and creative ideas that will contribute to the organization and are engaged in the work more than they are supposed to (Kelloway, Loughlin, Barling, \& Nault, 2002). OCB is generally examined under five categories: Conscientiousness is an employee exceeding the minimum performance he is supposed to exert. Altruism is helping other employees. Civic virtue is the contribution of an employee with the sense of self-responsibility for the future of the organization. Sportsmanship is employee's exhibition of a positive attitude without complaining. Courtesy is employee behaving in a respectful manner to the other employees (Organ, 1988).

The studies in the literature put forth that $O C B$ improves the administrative efficiency, contributes positively to the organizational performance indicators and to the students' academic achievement (DiPaola \& Hoy, 2005; Koys, 2001; Organ, 1988; Podsakoff, MacKenzie, Paine, \& Bachrach, 2000; Podsakoff \& MacKenzie, 1996; Walz \& Niehoff 1996). 


\section{Related Literature}

Studies in the related literature demonstrate that there is a meaningful relationship between leadership behaviours and JS (Bogler, 2001; Kim, 2002). A study carried out by Yılmaz and Ceylan (2011) shows that leadership behaviours of a school administrator affect teachers' JS levels. The study of Kim (2002) indicates that there is a positive relationship between JS and the management style in organizations, particularly participative management understanding has been shown to increase the subordinates' JS in the organizations. Findings of another research carried out by Hulpia, Devos and Rosseel (2009b) in Belgium reveal that there is a significant relationship between distributed leadership with OC and JS. The results of the study also reveal that coherence of leadership teams, the amount of leadership support, and the dimensions of distributed leadership, directly influence $\mathrm{OC}$ and indirectly influence JS.

Literature also reveals that the leadership behaviours exhibited by the administrator affect the OC level of subordinates. Meyer (1997) suggests that there is a relationship between leadership practices and OC of subordinates. Research in educational organizations discover that leadership approaches of the school principal affect OC level of teachers to their institutions (Nguni, Sleegers, \& Denessen, 2006). Jacobs (2010) ascertains that distributing leadership to entire stakeholders of a school, in particular teachers, increases teachers' commitment to their school. In a similar study Hulpia and Devos (2010) has examined the relationship between distributed leadership in schools and $\mathrm{OC}$ of teachers. According to the results of the study, the quality of leadership functions in the school, the distribution of leadership roles to the stakeholders of schools, social interaction, the cooperation of the leadership teams and the leadership practices such as participative leadership have been demonstrated to affect OC. The teachers who participated in the study state that accessibility of school principal, his ability to deal with the problems effectively, and his adoption of a participatory management style and his work of strictly observing daily activities of the teachers increase $\mathrm{OC}$ of teachers to their schools.

Previous research findings in the leadership literature indicate that leadership behaviours has an effect on OCB (Ilies, Nahrgang, \& Morgeson, 2007; Nguni et al., 2006; Podsakoff et al., 1996). In addition, the studies in educational organizations also reveal that leadership behaviours of school administrators have a positive impact on teachers' OCB (Çetin, Korkmaz, \& Çakmakçı, 2012; Koh, Steers, \& Terborg, 1995; Nguni et al., 2006; Oğuz, 2011). Another research from distributive perspective shows that distributed leadership is a significant and positive predictor of teacher's OCB (Kılınç, 2014).

Both in Turkish (Çetin et al., 2012; Oğuz, 2011; Yılmaz \& Ceylan, 2011), and international literature (Bogler, 2001; Kim, 2002; Hulpia et al., 2009b; Jacobs, 2010; Nguni et al., 2006; Podsakoff et al., 1996) there are numerous studies examining the relationship between different leadership approaches with teachers' JS, OC and OCB. However, there are few research studies (Berjaoui \& Karami-Akkary, 2019; Hulpia \& Devos, 2010; Hulpia et al., 2009b; Jacobs, 2010; Kılınç, 2014) dealing with distributed leadership and its relationship with the organizational variables.

\section{Significance}

Several theories have been developed regarding distributed leadership in educational organizations in the area of educational administration (Gronn, 2000; Harris, 2010; Hulpia, Devos, \& Van Keer, 2009; Jacobs, 2010; Leithwood et al., 2009; Spillane, 2006). However, there isn't adequate information about the effects of distributed leadership on the realization of organizational objectives and organizational variables (Anderson, Moore, \& Sun, 2009). Therefore, distributed leadership practices of school principals and the effects of this new approach on schools and teachers should be examined (Smith, Ross, \& Robichaux, 2004).

Although the distributed leadership concept is becoming popular in the literature; there are very few empirical studies examining its impacts on the staff of the organization (Hulpia et al., 2009b; Spillane, Camburn, \& Pareja, 2009; Townsend, 2011). Research which will be carried out in this subject will help to create a wider agenda on the most appropriate forms of organization in educational environments (Leithwood et al., 2009).

\section{Research Questions}

With this background in mind, the aim of this study is to examine whether distributed leadership has an effect on the teachers' job satisfaction (JS), organizational commitment (OC) and organizational citizenship behaviour (OCB). To achieve this aim, we formed three research questions:

i) Does the distributed leadership have significant effect on the teachers' job satisfaction?

ii) Does the distributed leadership have significant effect on the teachers' organizational citizenship behaviour?

iii) Does the distributed leadership have significant effect on the teachers' organizational commitment?

\section{METHODOLOGY}

In the study at hand, standard multiple regression analysis in the framework of quantitative research approach was employed as research method. Multiple regression is a statistical analysis used for discovering possible relationships among two or more variables. Multiple regression analysis involves a variable to be explained (Dependent Variable) and two or more explanatory variables (Independent Variable) that thought to be associated with changes in the dependent variable (NRC 2011, p.305). In this study, to determine the possible effects of distributed leadership on the OCB, OC and JS, we carried out 3 separate multiple regression analyses. In each analysis each one of OCB, OC and JS were taken as dependent variables and sub-dimensions of distributed leadership (Leadership Functions and Coherent Leadership Team) were taken as independent variables. SPSS 16.0 software package was used for analyses. 
Table 1. Distribution of the participants according to gender and seniority

\begin{tabular}{|c|c|c|}
\hline & Frequency & Percentage (\%) \\
\hline \multicolumn{3}{|l|}{ Gender } \\
\hline Female & 171 & 49.7 \\
\hline Male & 173 & 50.3 \\
\hline \multicolumn{3}{|l|}{ Seniority } \\
\hline $1-5$ Years & 77 & 22.4 \\
\hline $6-10$ Years & 115 & 33.5 \\
\hline 11-15 Years & 97 & 28.2 \\
\hline $16-20$ Years & 27 & 7.8 \\
\hline 21 years and more & 28 & 8.1 \\
\hline Total & 344 & 100 \\
\hline
\end{tabular}

\section{Sample}

Data were collected from teachers working at 15 randomly selected primary schools in Gaziantep city of Turkey. Gaziantep city, located in south-eastern region and with its $1.85 \mathrm{M}$ population, is one of the biggest cities in Turkey. The city has about 1,500 educational institutions, 710,000 students and 34,000 education staff (MoNE, 2017). In the 2016-2017 school-term, 435 questionnaires were distributed to primary school teachers. Totally 385 questionnaires were returned and of those returned 344 were considered valid. Table 1 shows demographic information about the sample.

\section{Data Collection Tools}

In the data collection phase of the study, four valid and reliable scales were used. For collecting data related to participant teachers' perceptions about distributed leadership in their schools Distributed Leadership Inventory (DLI) developed by Hulpia, Devos, and Rosseel (2009a) and adapted Turkish by Özdemir (2012) was employed. Original form of DLI was comprised of 3 sub dimensions; Coherent Leadership Team (10 items); Leadership Support (10 items) and Leadership Supervision ( 3 items). While adapting the DLI, Özdemir (2012) obtained 2-factors; Coherent Leadership Team (10 items) and Leadership Functions (13 items). In this study, internal reliability of the DLI was very high (Cronbach's Alpha 0.97). The responses for items of the scale ranges from "agree strongly=1" to "strongly disagree=5".

The Job Satisfaction Scale developed by Andrews and Whitney (1976) was used to determine teachers' JS level. The scale is comprised of five items and shows high correlation $(r=0.70)$ with the scales such as Job Descriptive Index and Minnesota Satisfaction Questionnaire (Rentsch \& Steel, 1992). Questions were scored on a Likert-type scale, 1 being "Terrible" and 5 being "Delighted." In this study, the scale was adapted to Turkish. After the adaptation, a single factorial structure was gained as in the original form of the scale. Cronbach's alpha coefficient of the scale was calculated as 0.79 .

To measure the participants' organizational commitment level, the Organizational Commitment Scale developed by Meyer and Allen (1991) and adapted to Turkish by Baysal and Paksoy (1999) was used. Consisting of 16 items, the scale is a five-point Likert response set that ranges from "Strongly Disagree $=1$ " and "Strongly Agree $=5$ ". Cronbach's alpha reliability co-efficient for overall scale was calculated as 0.89 for this study. The analyses were performed by using participants' OC points gained from overall scale.

Organizational Citizenship Behavior Scale developed by DiPaola, Tarter and Hoy (2005) and adapted to Turkish by Taşdan and Yılmaz (2008) was used to measure the OCB level of participants. The scale consists of 12 likert type items and it is single factorial. For this study, Cronbach's alpha of the scale was calculated as 0.84 .

\section{Data Analysis}

To determine the effect of distributed leadership on OCB, OC and JS, multiple regression analysis was performed. At the first stage of the analysis, hypotheses of the regression analysis were tested. In this context, firstly, multicollinearity among variables was tested. As the correlations between the independent variables are less than .90 (Table 2), $\mathrm{Cl}<10, \mathrm{TV}>0.10$ and $\mathrm{VIF}<10$ (Table 2), it was understood that there isn't any multi dependency problem (Çokluk, Şekercioğlu, \& Büyüköztürk, 2012, p. 35-36). Secondly, outliers that affect the predictive power of regression analysis were excluded (Coakes, 2005, p. 169). Calculated Mahalanobis distance value, two independent variables $(d f=2)$ and the cases having critical chi-square value for $p=0.001$ and greater than 13.82 were excluded from analysis (Coakes, 2005, p. 174; Çokluk et al., 2012, p. 15). Lastly, considering the fact that points gather around the line at Normal P-P graphic, the points of Scatter Diagram Matrix show elliptical distribution and frequency of standardized residual values show normal distribution, it was understood that regression analysis ensured linearity and normality hypothesis (Coakes, 2005, p. 169; Çokluk et al. 2012, p. 18-29). Enter method was used in regression analysis. All the independent variables are included into analysis at the same time in this method. Besides, descriptive statistical techniques such as frequency percentage and arithmetic mean were used. 
Table 2. Pearson correlations, means and standard deviations of variables

\begin{tabular}{|c|c|c|c|c|c|c|c|}
\hline & 2 & 3 & 4 & 5 & 6 & Mean & $S D$ \\
\hline 1. Distributed Leadership (General) & $0.955^{\star}$ & $0.954^{\star}$ & $0.531^{\star}$ & $0.526^{\star}$ & $0.521^{\star}$ & 3.792 & 0.836 \\
\hline 2. Leadership Functions & & $0.822^{*}$ & $0.493^{*}$ & $0.544^{\star}$ & $0.524^{\star}$ & 3.709 & 0.879 \\
\hline 3.Coherent Leadership Team & & & $0.520^{\star}$ & $0.460^{\star}$ & $0.470^{\star}$ & 3.875 & 0.872 \\
\hline 4.JS & & & & $0.421^{*}$ & $0.441^{*}$ & 3.509 & 1.111 \\
\hline $5.0 C B$ & & & & & $0.511^{\star}$ & 3.634 & 0.629 \\
\hline $6 . \mathrm{OC}$ & & & & & & 3.329 & 0.779 \\
\hline
\end{tabular}

${ }^{*}$ Correlation is significant at the 0.01 level

Table 3. ANOVA results between variables

\begin{tabular}{lllll}
\hline & Const & $\boldsymbol{r}$ & $\boldsymbol{R}^{2}$ & $\boldsymbol{F}$ \\
\hline JS & 2.220 & 0.532 & 0.283 & 67.445 \\
\hline$O C B$ & 2.164 & 0.545 & 0.297 & 71.927 \\
\hline$O C$ & 1.514 & 0.529 & 0.279 & 0.000 \\
\hline
\end{tabular}

Table 4. Regression Coefficients

\begin{tabular}{|c|c|c|c|c|c|c|c|c|c|}
\hline & \multicolumn{3}{|c|}{$O C B$} & \multicolumn{3}{|c|}{ OC } & \multicolumn{3}{|c|}{ JS } \\
\hline & $\boldsymbol{\beta}$ & $t$ & $p$ & $\beta$ & $t$ & $p$ & $\beta$ & $t$ & $P$ \\
\hline Leadership Functions & 0.512 & 6.418 & 0.000 & 0.425 & 0.263 & 0.000 & 0.204 & 0.537 & 0,012 \\
\hline Coherent Leadership Team & 0.040 & 0.498 & 0.619 & 0.121 & 0.498 & 0.135 & 0.352 & 0.372 & 0.000 \\
\hline
\end{tabular}

\section{FINDINGS}

First of all, hypotheses of standard regression analysis were tested. The significance of regression models was given in Table $\mathbf{2}$, and individual effects of sub dimensions in Table 3.

Correlations between variables are shown in the Table 2 . As seen from the table, distributed leadership is positively correlated with JS $(r=0.531)$, OCB $(r=0.526)$ and OC $(r=0.521)$. All correlation coefficients are positive, moderately strong and statistically significant $(p<0.01)$. These results imply that distributing leadership roles throughout the school increases teachers' job satisfaction, commitment to school and positively affect their citizenship behaviours. In terms of sub-dimensions, Leadership functions were moderately correlated with JS $(r=0.493)$, OCB $(r=0.544)$ and OC $(r=0.524)$. Coherent Leadership Team subdimension was also moderately correlated with JS ( $r=0.520)$, OCB $(r=0.460)$ and OC $(r=0.470)$. There were also moderately strong, positive and statistically significant correlations among teachers' JS, OC and OCB. These findings imply that these variables positively affect each other. Finally, strong positive correlation between, Leadership Functions and Coherent Leadership Team sub-dimensions ( $r=0.822$ ) shows factorial validity of distributed leadership questionnaire.

When we look at mean and standard deviation; teachers state that leadership roles are generally distributed well in their schools $(M=3.792 ; S D=0.836)$. It is also seen that levels of leadership functions $(M=3.709 ; S D=0.879)$ and coherent leadership team sub-dimensions ( $M=3.875 ; S D=0.872)$ are high. Teachers' JS ( $M=3.509 ; S D=1.111)$ and OCB levels $(M=3.634 ; S D=0.629)$ are also high; and their OC level is moderate $(M=3.329 ; \mathrm{SD}=0.779)$.

As seen from the ANOVA test results shown in the Table 3, regression analysis carried out to determine the effect of distributed leadership on JS is statistically significant $(F(2,341)=67.445, p=0.000)$. That is, distributed leadership has an effect on participant teachers' JS and distribute leadership explains $28.3 \%$ of variance in teachers' JS. Distributed leadership also has an effect on the participants' $\operatorname{OCB}(F(2,341)=71.927, p=0.000)$ and distribute leadership explains $29.7 \%$ of variance in teachers' OCB. Finally, results of the regression analysis revealed that, distributed leadership's effect on OC of participant teachers is statistically significant $(F$ $(2,341)=66.100, p=0.000)$ and distribute leadership explains $27.9 \%$ of variance in teachers' $O C$.

Individual effects of distributed leaderships' sub-dimensions on JS, OC and OCB are shown on Table 4. While leadership functions sub-dimension is a valid predictor of OCB $(t=6.418, p<0.05)$, leadership team coherence is not a significant predictor $(p>0.05)$. Similarly, while leadership functions sub-dimension is also a valid predictor of OC $(t=5.263, p<0.05)$, leadership team coherence is not a significant predictor of OC $(p>0.05)$. Unlike this findings, both of the leadership functions $(t=2.537, p<0.05)$ and leadership team coherence $(t=4.372, p<0.05)$ sub-dimensions were valid predictors of the JS. Between these two variables leadership team coherence $(\beta=0.352)$ was a stronger predictor than leadership functions $(\beta=0.204)$ dimension.

\section{CONCLUSIONS AND DISCUSSIONS}

The aim of this study was to investigate the effects of distributed leadership on the teachers' JS, OCB and OC. Findings of the study showed that distributed leadership had a significant effect on teachers' JS, OCB and OC.

According to the first result of the research, distributed leadership affects teachers' JS. Both of the sub dimensions - coherent leadership team and leadership functions - affect teachers' JS level positively. More clearly, increasing coherence of leadership team and the level of leadership functions increases teachers' JS positively. The quality of education is closely related to teachers' opinions about their jobs and their JS level (Heller, Clay, \& Perkins 1993). Studies showed that leadership behaviours of managers 
affect JS level of their staff (Kim, 2002; Yılmaz \& Ceylan, 2011). Another research revealed that sharing leadership in educational organisations increases teachers' JS (Kim, 2002). In schools where distributed leadership practices are demonstrated, teachers are supported and encouraged to take active role in leadership process (Hulpia et al., 2009b). This situation increases teachers' desire to participate in the decision-making process and so their JS level is higher (Bogler, 2001; Hulpia et al., 2009b). Administrative competence of managers and their distributing leadership to teachers would increase the level of teachers' JS (Bogler, 2001).

According to second result of the research, distributed leadership affects teachers' OC. In terms of sub dimensions, the leadership functions dimension affects $\mathrm{OC}$ but the coherent leadership team dimension does not. This implies that teachers who feel supported will be highly committed towards their schools. This result is in line with findings of some previous research (Berjaoui \& Karami-Akkary, 2019; Hulpia et al., 2009b; Jacobs, 2010; Nguni et al., 2006). The findings of these research showed that behaviours and leadership approaches of school administrators affect teachers' OC to their schools. They also suggested that providing sufficient support is crucial for teachers' organizational commitment. Hulpia and Devos (2010) extended these findings with their study that this is true not only for the traditional one-man leadership, but also for distributed leadership. Similarly, Jacobs (2010) revealed that managers' sharing their leadership roles and presenting a democratic and participative leadership style will increase OC level of their subordinates. According to Hulpia et al. (2009b), the teachers working at schools in which leadership roles are clearly defined and distributed to groups/teams, collaborative leadership is adopted and where leadership teams work coherently, are more committed to their schools. The main reason for this situation is that subordinates are supported to participate in decision making process.

The last result of the research reveals that distributed leadership affects $O C B$ of teachers. However, in terms of sub dimensions, only the leadership functions dimension has an effect on OCB, but the coherent leadership team dimension has no effect on OCB. This result corroborates the research findings of Çetin et al. (2012), Koh et al. (1995), Nguni et al. (2006), and Oğuz (2011). The research indicated that supportive leadership approaches of school administrators have a strong positive effect on teachers' OCB. Another study also revealed that distributed leadership is a significant positive predictor of teacher OCBs (Kılınç, 2014). Teachers become more motivated to take active role and perform beyond minimum expectations in school when their principals give positive feedback to teachers, provide them with professional autonomy, share managerial decisions with them, and support them emotionally (Oplatka, 2006).

Administrators, alone, are not enough for school transformation to take place (Hall and Hord 2001). Thus, it is necessary to distribute leadership among stakeholders of the school for a sustainable school development (Bush \& Glover, 2012; Davies \& Brundrett, 2010; Gronn, 2000; Northouse, 2013; Spillane, 2006; Spillane et al., 2009). In light of this research, it becomes apparent teachers are better at their jobs when the leadership of a school is shared, and this "perspective suggests that leadership within a school is distributed among many actors. In other words, leadership is not the purview of administrators only, but is exercised by people in many positions" (Furman, 2003, p. 4).

Effective educational leaders are not leaders by force; they are leaders because they encourage and support others in using their abilities to serve students. "Leadership is not about personality; it's about behaviour" (Kouzes \& Posner, 2007, p. 15). This behaviour includes leading by example, distributing leadership roles to involve all stakeholders in using their strengths to serve students, stretching their abilities, and most of all, partaking in the process of meeting the needs of students. Sharing leadership will grow leadership abilities within the school community. Furman (2003) suggests, "the total amount of leadership in a school matters and that leadership multiplies through interaction" (p.4). As people are involved in leadership opportunities, they become more deeply connected to the issues within the school community, more passionate about doing what is right for students, and more involved in making changes to benefit the students within our school. When people are trusted and have more discretion, more authority, and more information, they will be much more motivated and committed to their organisation and perform beyond expected performance to produce extraordinary results (Kouzes \& Posner, 2007).

\section{Suggestions}

In today's world, managing schools effectively is becoming more and more complex. In this regard, school leaders cannot lead schools alone. Therefore, they build a trusting, encouraging community that works toward a shared vision. Leaders share the decision making with others, knowing that everyone involved in the school community has something valuable to give. Leaders also recognize leadership attributes within others and support and encourage them to grow and develop these skills.

In this regard, increasing awareness and supporting capabilities of educational leaders on this issue, local and governmental educational bodies (such as school board and Ministry of Education) should update pre-service and in-service training programs in such a way that they include distributed leadership and related courses. Besides, policy makers and top managers should be pioneers and role models for school principals in distributing leadership by sharing their leadership role and duties with their subordinates. In this way, JS, OC, and OCB level of teachers will increase and that will help schools to increase their performance. In other words, in the all levels of educational institutions, the schools or any other level of educational institutions might their organisational targets if the principals/managers create some leadership teams for distributing their own power and authority.

\section{Limitations}

The current study has some limitations and further research is needed. In this study, we used the distributed leadership framework which was defined by Hulpia, Devos, and Rosseel (2009a). And we also used DLI which was developed by Hulpia and her colleagues. However, one might suggest that similar research can be performed with different a DL framework and different scales. 
Another limitation of the study is that we used the quantitative research in this study. The quantitative research instrument had its limitations. Future research should use other sources for investigating the study variables. Qualitative research methods could extend the understanding of how JS, OC, and OCB is influenced by DL.

We also suggest that replicating similar research at different educational settings in different cultures. This will make a major to the literature. Another area that needs investigating includes the characteristics of leaders who are successful at distributing leadership. What makes one leader successful at sharing the work; while others clearly seem to hold on to the power that comes with leading. Our data show teachers are more successful under a distributive model of leadership. So, what makes the leader lead in that fashion?

\section{REFERENCES}

Allen, N. J., \& Meyer, J. P. (1990). The measurement and antecedents of affective, continuance, and normative commitment to the organization. Journal of Occupational Psychology, 63(1), 1-18. https://doi.org/10.1111/j.2044-8325.1990.tb00506.x

Anderson, S. E., Moore, S., \& Sun, J. (2009). Positioning the principals in patterns of school leadership distribution. In K. Leithwood, B. Mascall, \& T. Strauss (Eds.), Distributed leadership according to the evidence. New York: Routledge.

Andrews, F. M., \& Withey, S. B. (1976). Social indicators of well-being: Americans' perceptions of life quality. New York: Plenum Press. https://doi.org/10.1007/978-1-4684-2253-5

Baysal, A. C., \& Paksoy, M. (1999). Mesleğe ve örgüte bağlılığın çok yönlü incelenmesinde Meyer-Allen modeli [A multi-faceted investigation of professional and organizational commitment: The Meyer-Allen model]. İstanbul Üniversitesi Iş̧letme Fakültesi Dergisi, 2(1), 7-15.

Berjaoui, R. R., \& Karami-Akkary, R. (2019). Distributed Leadership as a Path to Organizational Commitment: The Case of a Lebanese School. Leadership and Policy in Schools, 1-15. https://doi.org/10.1080/15700763.2019.1637900

Blau, G. J., and Boal, K. R. (1987). Conceptualizing how job involvement and organizational commitment affect turnover and absenteeism. Academy of Management Review, 17(2), 288-301. https://doi.org/10.5465/AMR.1987.4307844

Bogler, R. (2001). The influence of leadership style on teacher job satisfaction. Educational Administration Quarterly, 37(5), 662683. https://doi.org/10.1177/00131610121969460

Bush, T. (2011). Theories of educational leadership and management (4 ed.). London: Sage.

Bush, T. (2012). Enhancing leadership density through teamwork. Educational Management Administration \& Leadership, 40(6), 649-652. https://doi.org/10.1177/1741143212457553

Bush, T. (2018). School leadership theories and the Malaysia Education Blueprint. International Journal of Educational Management, 32(7), 1245-1265. https://doi.org/10.1108/IJEM-06-2017-0158

Bush, T., \& Glover, D. (2012). Distributed leadership in action: Leading high-performing leadership teams in English schools. School Leadership \& Management, 32(1), 21-36. https://doi.org/10.1080/13632434.2011.642354

Çetin, Ş., Korkmaz, M., \& Çakmakçı, C. (2012). Effects of transformational and transactional leadership and leader-member exchange on teachers' organizational citizenship behaviors. Educational Administration: Theory and Practice, 18(1), 7-36.

Clegg, S., Clarke, T., \& Ibarra, E. (2001). Millennium management, changing paradigms and organizational studies. Human Relations, 54(1), 31-36. https://doi.org/10.1177/0018726701541005

Coakes, S. J. (2005). SPSS: Analysis without Anguish Using SPSS Version 12. 0 for Windows. Australia: Wiley \& Sons.

Çokluk, Ö., Şekercioğlu, G., \& Büyüköztürk, Ş. (2010). Sosyal Bilimler için Çok Değişkenli i̇statistik [Multivariate Statistics for Social Sciences]. Ankara: Pegem Akademi.

Crawford, M. (2012). Solo and distributed leadership: Definitions and dilemmas. Educational Management Administration \& Leadership, 40(5), 610-620. https://doi.org/10.1177/1741143212451175

Davies, B., \& Brundrett, M. (2010). Developing Successful Leadership. In K. Leithwood (Ed.), Studies in Educational Leadership. New York: Springer. https://doi.org/10.1007/978-90-481-9106-2

Dee, J. R., Henkin, A. B., \& Singleton, C. A. (2006). Organizational commitment of teachers in urban schools: Examining the effects of team structures. Urban Education, 41(6), 603-627. https://doi.org/10.1177/0042085906292512

DiPaola, M. F., \& Hoy, W. K. (2005). Organizational citizenship of faculty and achievement of high school students. The High School Journal, 88(3), 35-44. https://doi.org/10.1353/hsj.2005.0002

DiPaola, M., Tarter, C., \& Hoy, W. K. (2005). Measuring organizational citizenship in schools: The OCB scale. In W. K. Hoy \& C. G. Miskel (Eds.), Educational leadership and reform (pp. 319-341). Greenwich, CN: Information Age.

Fink, S. L. (1992). High commitment workplaces. New York: Quorum Books.

Fullan, M. (1993). Change forces: Probing the depths of educational reform. London: The Falmer Press.

Furman, G. (2003). The 2002 UCEA presidential address. UCEA Review, XLV(1), 1-6.

Gronn, P. (2000). Distributed properties: A new architecture for leadership. Educational Management Administration \& Leadership, 28(3), 317-338. https://doi.org/10.1177/0263211X000283006

Hall, G., \& Hord, S. (2001). Implementing change: Patterns, principles, and potholes. Boston: Allyn \& Bacon. 
Harris, A. (2010). Distributed leadership. In T. Bush, L. Bell \& D. Middlewood (Eds.), The principles of educational leadership and management (pp. 55-69). London: Sage.

Harris, A., \& DeFlaminis, J. (2016). Distributed leadership in practice: Evidence, misconceptions and possibilities. Management in Education, 30(4), 141-146. https://doi.org/10.1177/0892020616656734

Hartley, D. (2010). Paradigms: How far does research in distributed leadership 'Stretch'? Educational Management Administration \& Leadership, 38(3), 271-285. https://doi.org/10.1177/1741143209359716

Heller, H. W., Clay, R., \& Perkins, C. (1993). The relationship between teacher job satisfaction and principal leadership style. Journal of School Leadership, 3(1), 74-86. https://doi.org/10.1177/105268469300300108

Hulpia, H., \& Devos, G. (2010). How distributed leadership can make a difference in teachers' organizational commitment? A qualitative study. Teaching and Teacher Education, 26(3), 565-575. https://doi.org/10.1016/j.tate.2009.08.006

Hulpia, H., Devos, G., \& Rosseel, Y. (2009a). Development and validation of scores on the distributed leadership inventory. Educational and Psychological Measurement, 69(6), 1013-1034. https://doi.org/10.1177/0013164409344

Hulpia, H., Devos, G., \& Rosseel, Y. (2009b). The Relationship between the perception of distributed leadership in secondary schools and teachers' and teacher leaders' job satisfaction and organizational commitment. School Effectiveness and School Improvement, 20(3), 291-317. https://doi.org/10.1080/09243450902909840

Hulpia, H., Devos, G., \& Van Keer, H. (2009). The influence of distributed leadership on teachers' organizational commitment: A multilevel approach. The Journal of Educational Research, 103(1), 40-52. https://doi.org/10.1080/00220670903231201

Ilies, R., Nahrgang, J. D., \& Morgeson, F. P. (2007). Leader-member exchange and citizenship behaviors: a meta-analysis. Journal of applied psychology, 92(1), 269-277. https://doi.org/10.1037/0021-9010.92.1.269

Jacobs, G. E. (2010). The relationship between distributed leadership as practiced by principals and the organizational commitment of teachers (Unpublished PhD Diss.). Graduate Faculty of Georgia Southern University.

Judge, T. A., Thoresen, C. J., Bono, J. E., \& Patton, G. K. (2001). The job satisfaction-job performance relationship: A qualitative and quantitative review. Psychological Bulletin, 127(3), 376-407. https://doi.org/10.1037/0033-2909.127.3.376

Kelloway, E. K., Loughlin, C., Barling, J., \& Nault, A. (2002). Self - reported counterproductive behaviors and organizational citizenship behaviors: Separate but related constructs. International Journal of Selection and Assessment, 10(1-2), 143-151. https://doi.org/10.1111/1468-2389.00201

Kılınç, A. Ç. (2014). A Quantitative study of the relationship between distributed leadership and organizational citizenship behavior: Perceptions of Turkish primary school teachers. Journal of Curriculum and Teaching, 3(2), 69-78. https://doi.org/10.5430/jct.v3n2p69

Kim, S. (2002). Participative management and job satisfaction: Lessons for management leadership. Public Administration Review, 62(2), 231-241. https://doi.org/10.1111/0033-3352.00173

Koh, W. L., Steers, R. M., \& Terborg, J. R. (1995). The effects of transformational leadership on teacher attitudes and student performance in Singapore. Journal of Organizational Behavior, 16(4), 319-333. https://doi.org/10.1002/job.4030160404

Kouzes, J. M., \& Posner, B. Z. (2007). The leadership challenge (4th ed.). San Francisco, CA: Jossey-Bass.

Koys, D. J. (2001). The effects of employee satisfaction, organizational citizenship behavior, and turnover on organizational effectiveness: A unit-level, longitudinal study. Personnel Psychology, 54(1), 101-114. https://doi.org/10.1111/j.17446570.2001.tb00087.x

Leithwood, K., Harris, A., \& Hopkins, D. (2008). Seven strong claims about successful school leadership. School Leadership \& Management, 28(1), 27-42. https://doi.org/10.1080/13632430701800060

Leithwood, K., Mascall, B., \& Strauss, T. (Eds.). (2009). Distributed leadership according to the evidence. New York: Routledge. https://doi.org/10.4324/9780203868539

Locke, E. A. (1976). The nature and causes of job satisfaction. In M. D. Dunnette (Ed.), Handbook of industrial and organizational psychology (pp. 1297-1349). Chicago: Rand McNally.

MacBeath, J. (2005). Leadership as distributed: a matter of practice. School Leadership and Management, 25(4), 349-366. https://doi.org/10.1080/13634230500197165

Meyer, J. P., \& Allen, N. J. (1991). A three-component conceptualization of organizational commitment. Human Resource Management Review, 1(1), 61-89. https://doi.org/10.1016/1053-4822(91)90011-Z

Meyer, J., \& Allen, N. (1997). Commitment in the Workplace. CA: Sage.

MoNE. (2017). National Education Statistics - Formal Education 2016/'17. Ankara: Ministry of National Education (MoNE) Strategy $\begin{array}{llllll}\text { Development } \quad \text { Presidency. } & \text { Retrieved } & 10 & \text { December } & 2017 & \text { from }\end{array}$ https://sgb.meb.gov.tr/meb_iys_dosyalar/2017_09/08151328_meb_istatistikleri_orgun_egitim_2016_2017.pdf

Newstrom, J. W., \& Davis, K. (1993). Organizational behavior: Human behavior at work (9th ed.). New York: McGraw-Hill.

Nguni, S., Sleegers, P., and Denessen, E. (2006). Transformational and transactional leadership effects on teachers' job satisfaction, organizational commitment, and organizational citizenship behavior in primary schools: The Tanzanian case. School Effectiveness and School Improvement, 17(2), 145-177. https://doi.org/10.1080/09243450600565746

Northouse, P. G. (2013). Leadership: Theory and Practice (6th ed.). CA: Sage. 
NRC. (2011). Reference Manual on Scientific Evidence (3rd ed.). Washington, DC: The National Academies Press. https://doi.org/10.17226/13163

Oğuz, E. (2011). The relationship between the leadership styles of the school administrators and the organizational citizenship behaviors of teachers. Educational Administration: Theory and Practice, 17(3), 377-403.

Oplatka, I. (2006). Going beyond role expectations: Toward an understanding of the determinants and components of teacher organizational citizenship behavior. Educational Administration Quarterly, 42(3), 385-423. https://doi.org/10.1177/ $0013161 \times 05285987$

Organ, D. W. (1988). Organizational citizenship behavior: The good soldier syndrome. Lexington, MA \& Toronto: Lexington Books/DC Heath and Com.

Ostroff, C. (1992). The Relationship between satisfaction, attitudes, and performance: An organizational analysis. Journal of Applied Psychology, 77(6), 963-974. https://doi.org/10.1037/0021-9010.77.6.963

Özdemir, M. (2012). Turkish adaptation of distributed leadership inventory: The validity and reliability studies. Educational Administration: Theory and Practice, 18(4), 575-598.

Podsakoff, P. M., MacKenzie, S. B., \& Bommer, W. H. (1996). Transformational leader behaviors and substitutes for leadership as determinants of employee satisfaction, commitment, trust, and organizational citizenship behaviors. Journal of Management, 22(2), 259-298.

Podsakoff, P. M., MacKenzie, S. B., Paine, J. B., \& Bachrach, D. G. (2000). Organizational citizenship behaviors: A critical review of the theoretical and empirical literature and suggestions for future research. Journal of Management, 26(3), 513-563. https://doi.org/10.1177/014920630002600307

Rentsch, J. R., \& Steel, R. P. (1992). Construct and concurrent validation of the Andrews and Withey Job Satisfaction Questionnaire. Educational and Psychological Measurement, 52(2), 357-367. https://doi.org/10.1177/0013164492052002011

Sergiovanni, T. J. (1987). The principalship: A reflective practice perspective. Newton, MA: Allyn \& Bacon.

Smith, R. W., Ross, M., \& Robichaux, R. (2004). Creation and validation of a measure of leadership density in elementary and middle schools. The Journal of Research for Educational Leaders, 2(2), 79-111.

Spillane, J. P. (2006). Distributed leadership. San Francisco: Jossey-Bass.

Spillane, J. P., Camburn, E. M., \& Pareja, A. S. (2009). School principals at work: A distributed perspective In K. Leithwood, B. Mascall \& T. Strauss (Eds.), Distributed leadership according to the evidence. New York: Routledge.

Spillane, J., \& Anderson, L. (2019). Negotiating Policy Meanings in School Administrative Practice: Practice, Professionalism, and High-Stakes Accountability in a Shifting Policy Environment. In D. Hung, S. Lee, Y. Toh, A. Jamaludin \& L. Wu (Eds.), Innovations in Educational Change. Education Innovation Series. Singapore: Springer. https://doi.org/10.1007/978-981-13-6330-6_7

Supovitz, J. A., D’Auria, J., \& Spillane, J. P. (2019). Meaningful \& Sustainable School Improvement with Distributed Leadership CPRE Research Reports. Retrieved on 24 September 2019 from https://repository.upenn.edu/cpre_researchreports/112

Tam, A. (2018). Conceptualizing Distributed Leadership: Diverse Voices of Positional Leaders in Early Childhood Education. Leadership and Policy in Schools, 1-18. https://doi.org/10.1080/15700763.2018.1513156

Taşdan, M., \& Yılmaz, K. (2008). Organizational citizenship and organizational justice scales' adaptation to Turkish. TED Education and Science, 33(150), 87-96.

Townsend, T. (2011). School Leadership in the twenty-first century: Different approaches to common problems? School Leadership \& Management, 31(2), 93-103. https://doi.org/10.1080/13632434.2011.572419

Tschannen-Moran, M. (Ed.). (2003). Fostering organizational leadership: Transformational leadership and trust. Greenwich: CT: Information Age Publishing.

Valentine, S., Godkin, L., \& Lucero, M. (2002). Ethical context, organizational commitment, and person-organization fit. Journal of Business Ethics, 41(4), 349-360. https://doi.org/10.1023/A:1021203017316

Walz, S. M., \& Niehoff, B. P. (1996). Organizational citizenship behaviors and their effect on organizational effectiveness In limitedmenu restaurants. Paper presented at the Academy of Management Proceedings. https://doi.org/10.5465/ambpp.1996. 4980770

Weiss, C. H., \& Cambone, J. (2000). Principals, shared decision making, and school reform. The Jossey-Bass Reader on Educational Leadership (pp. 366-389). San Francisco: Jossey-Bass Publishing.

Yılmaz, A., \& Ceylan, Ç. B. (2011). Relationship between primary school administrators' leadership behavior and job satisfaction of teachers. Educational Administration: Theory and Practice, 17(2), 277-394. 